\title{
КЛИНИЧЕСКАЯ И ЛАБОРАТОРНО-ИНСТРУМЕНТАЛЬНАЯ ХАРАКТЕРИСТИКА БОЛЬНЫХ ХГ С
}

\section{CLINICAL AND LABORATORY- INSTRUMENTAL CHARACTERISTICS OF PATIENTS WITH CHRONIC HEPATITIS C \\ S. Mammaev \\ A. Muskhadzhiev \\ O. Komissarova}

Summary. The article presents the features of the clinical manifestations of chronic hepatitis C in patients at the time of inclusion in the study, the main biochemical parameters of the blood of patients with chronic hepatitis C, as well as the main indicators of the laboratory study of patients of the main group and the comparison group.

Keywords: hepatitis, research, asthenic syndrome, cytolytic enzyme fibroelastoma, enzyme-linked immunosorbent assay.

$\mathbf{X}$ Г С был диагностирован у 150 больных. Возраст больных варьировал от 19 до 59 лет (средний

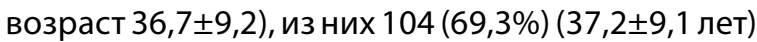
мужчины и 46 (30,7\%) (35,8土10,6 лет) женщин. Исследование проводилось на базе медицинского центра «Гепар» г. Махачкала.

Различие по возрасту между мужчинами и женщинами недостоверное $(p=0,48)$.

У 108 (72\%) пациентов продолжительность заболевания (по данным анамнеза) составила до 10 лет, у 42 (28\%) более 10 лет (рис. 1).

Пациенты жаловались на вялость, слабость, быструю утомляемость, снижение трудоспособности, неинтенсивные ноющие боли в правом подреберье, не связанные с приемом пищи; периодически - желтушное окрашивание склер.

Астенический синдром, который проявлялся повышенной утомляемостью, ослаблением способности к продолжительному физическому и умственному напряжению, раздражимостью, повышенной возбудимостью, понижением настроения, слезливостью, непереносимостью яркого света, громких звуков и резких
Маммаев Сулейман Нураттинович

Д.м.н., профессор, ФГБОУВО «Дагестанский государственный медицинский университет» МЗ РФ

dgma@list.ru

Мусхаджиев Алимхан Абухаджиевич

К.м.н., ассистент, ФГБОУ ВО «Дагестанский государственный медицинский университет» МЗ РФ muskhadzhiyev76@list.ru

Комиссарова Ольга Николаевна Ассистент, ФГБОУ ВО «Дагестанский государственный медицинский университет» МЗ РФ dgma_mo@mail.ru

Аннотация. С статье представлены особенности клинических проявлений ХГ С у больных на момент включения в исследование, основные биохимические показатели крови больных ХГ С, а также представлены основные показатели лабораторного исследования больных основной группы и группы сравнения.

Ключевые слова: гепатит, исследование, астенический синдром, цитолитический фермент, фиброэластометрия, иммуноферментный анализ.

запахов различной степени выраженности, выявлен у 96 (64,0\%) больных. В соответствии с оценкой функционального статуса астения в 0 баллов оценена у 127 (84,7\%) больных, в 1 балл у 23 (15,3\%).

Болевой синдром наблюдался у 68 (45,3\%) пациентов ХГ С, из них слабо выраженной степени у 52 (34,7\%), умеренно выраженный у 16 (10,6\%) больных.

Стойкое повышение температуры тела до субфебрильных цифр наблюдалось у 58 (38,7\%) больных.

Симптомы, выявленные при физикальном обследовании, включали: желтуху различной степени выраженности, увеличение размеров печени и селезенки, болезненность печени при пальпации.

Субиктеричность склер наблюдалась у 34 (22,7\%) больных, желтушное окрашивание склер и кожи у 14 $(9,3 \%)$.

Увеличение печени на 1-2 см отмечалось у 92 (61,3\%) больных, на 3-4 см - у 23 (15,3\%).

У 35 (23,3\%) больных ХГ С выявлено увеличение длинника селезенки на 1-2 см. 
Таблица 1. Основные показатели биохимического анализа крови у больных ХГ С ( $\mathrm{n}=150)$

\begin{tabular}{|l|l|l|}
\hline Показатель & Больные ХГ С, (n=150) $\mathbf{M} \pm \mathbf{m}$ & Норма \\
\hline Общий белок, г/л & $72,1 \pm 1,4$ & $60-85$ \\
\hline Альбумин, г/л & $41,5 \pm 1,2$ & $35-50$ \\
\hline Общий билирубин, мкмоль/л & $23,7 \pm 3,1$ & $3,4-22,2$ \\
\hline Прямой билирубин, мкмоль/л & $0-5,4$ \\
\hline ПИ,\% & $9,1 \pm 1,5$ & $85-105$ \\
\hline АсАТ, МЕ & $89,6 \pm 2,1$ & до 30 \\
\hline АлАТ, МЕ & $70,4 \pm 38,9$ & до 30 \\
\hline Щ, ед./л & $76,3 \pm 36,8$ & до 180 \\
\hline ГГТ, МЕ & $149,2 \pm 16,1$ & до 61 \\
\hline
\end{tabular}

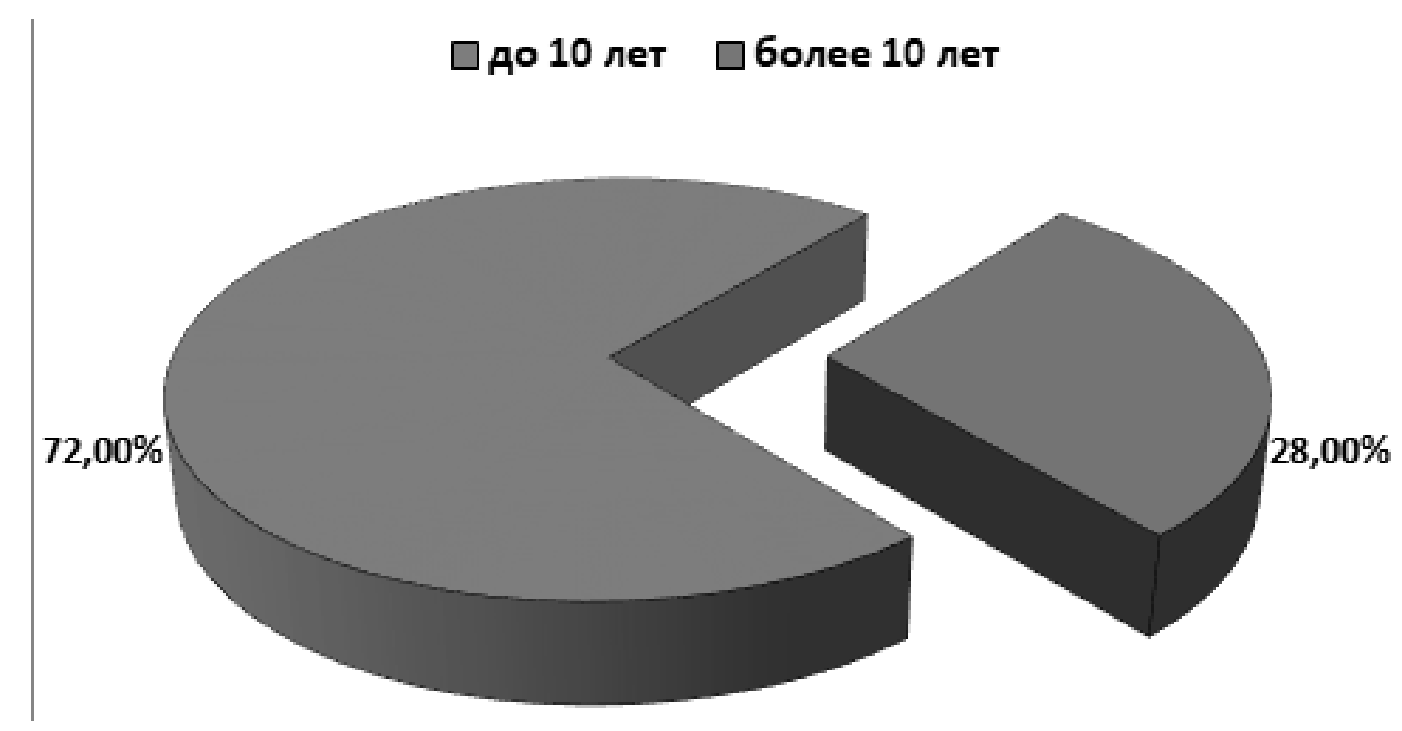

Рис. 1. Распределение больных ХГ С в зависимости от длительности заболевания (n=150).

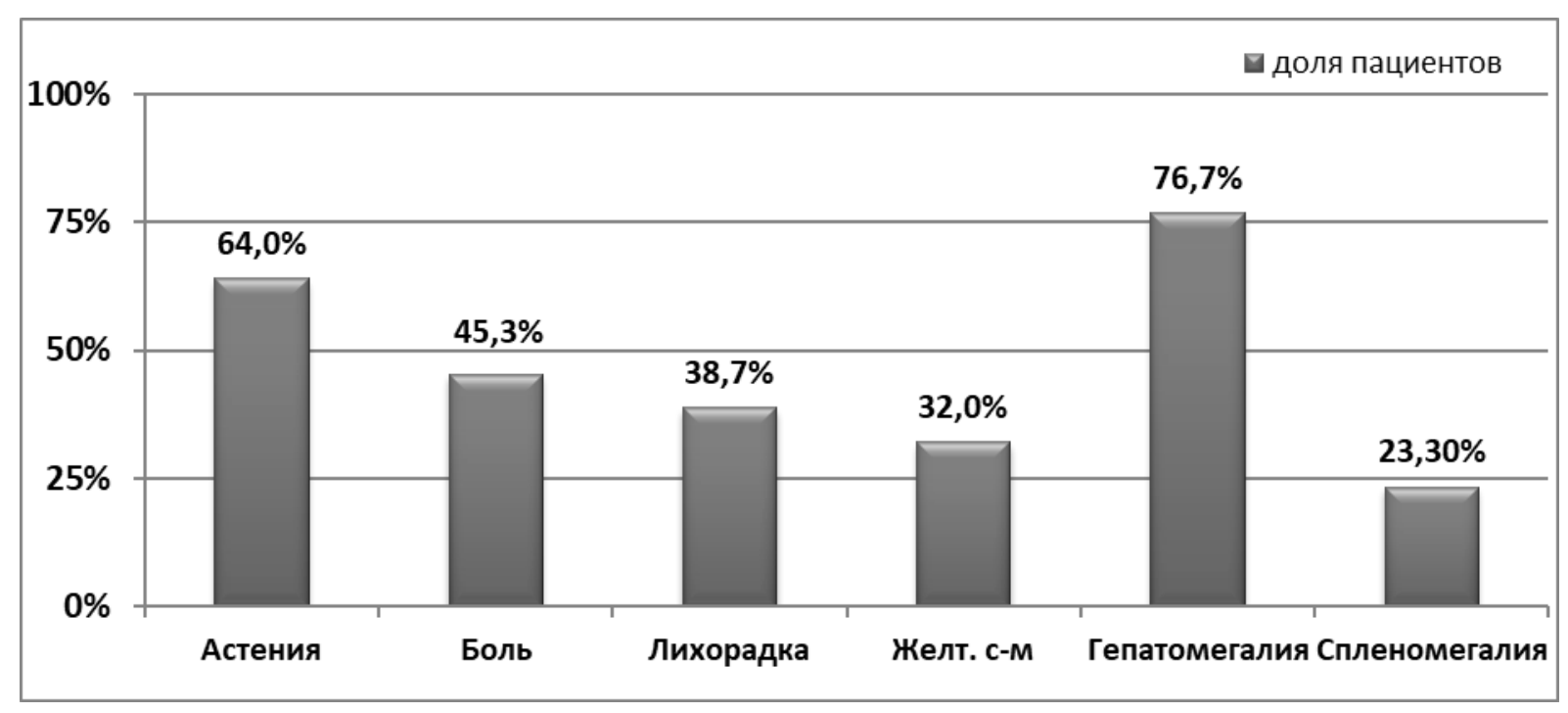

Рис. 2. Клинические проявления больных ХГ С. 
Таблица 2. Маркеры ВГ С у обследованных больных

\begin{tabular}{|l|l|l|l|l|l|l|l|}
\hline Группа & Anti HCV+ & $\begin{array}{l}\text { HCV } \\
\text { RNA }\end{array}$ & Генотип 1 & Генотип 2 & Генотип 3 & $\begin{array}{l}>800000 \text { ME/ } \\
\text { мл }\end{array}$ & $\begin{array}{l}<800000 ~ M E / ~ \\
\text { мл }\end{array}$ \\
\hline ХГC & $100 \%$ & $100 \%$ & $65,3 \%$ & $10,0 \%$ & $24,7 \%$ & $41,3 \%$ & $58,7 \%$ \\
\hline
\end{tabular}

Таблица 3. Лабораторные показатели у больных ХГ С основной группы $(n=150)$ и группы сравнения $(n=45)$

\begin{tabular}{|l|l|l|l|}
\hline Показатели & $\begin{array}{l}\text { Группа } \\
\text { основная } \\
(\mathbf{n = 1 5 0 )}\end{array}$ & $\begin{array}{l}\text { Группа } \\
\text { сравнения } \\
\text { (n=45) }\end{array}$ & $\mathbf{p}$ \\
\hline Общий белок, г/л & $72,1 \pm 1,4$ & $72,8 \pm 2,1$ & $>0,05$ \\
\hline Альбумин, г/л & $41,5 \pm 1,2$ & $43,8 \pm 1,4$ & $>0,05$ \\
\hline Общий билирубин, мкмоль/л & $23,7 \pm 3,1$ & $21,6 \pm 1,9$ & $>0,05$ \\
\hline Прямой билирубин, мкмоль/л & $9,1 \pm 1,5$ & $10,7 \pm 1,4$ & $>0,05$ \\
\hline ПИ,\% & $89,6 \pm 2,1$ & $90,2 \pm 3,2$ & $>0,05$ \\
\hline АСТ, МЕ & $70,4 \pm 38,9$ & $64,6 \pm 34,5$ & $>0,05$ \\
\hline АЛТ, МЕ & $76,3 \pm 36,8$ & $72,8 \pm 42,8$ & $>0,05$ \\
\hline ЩФ, Ед/л & $149,2 \pm 16,1$ & $139,1 \pm 14,2$ & $>0,05$ \\
\hline ГТ, МЕ & $47,3 \pm 5,5$ & $43,8 \pm 5,7$ & $>0,05$ \\
\hline
\end{tabular}

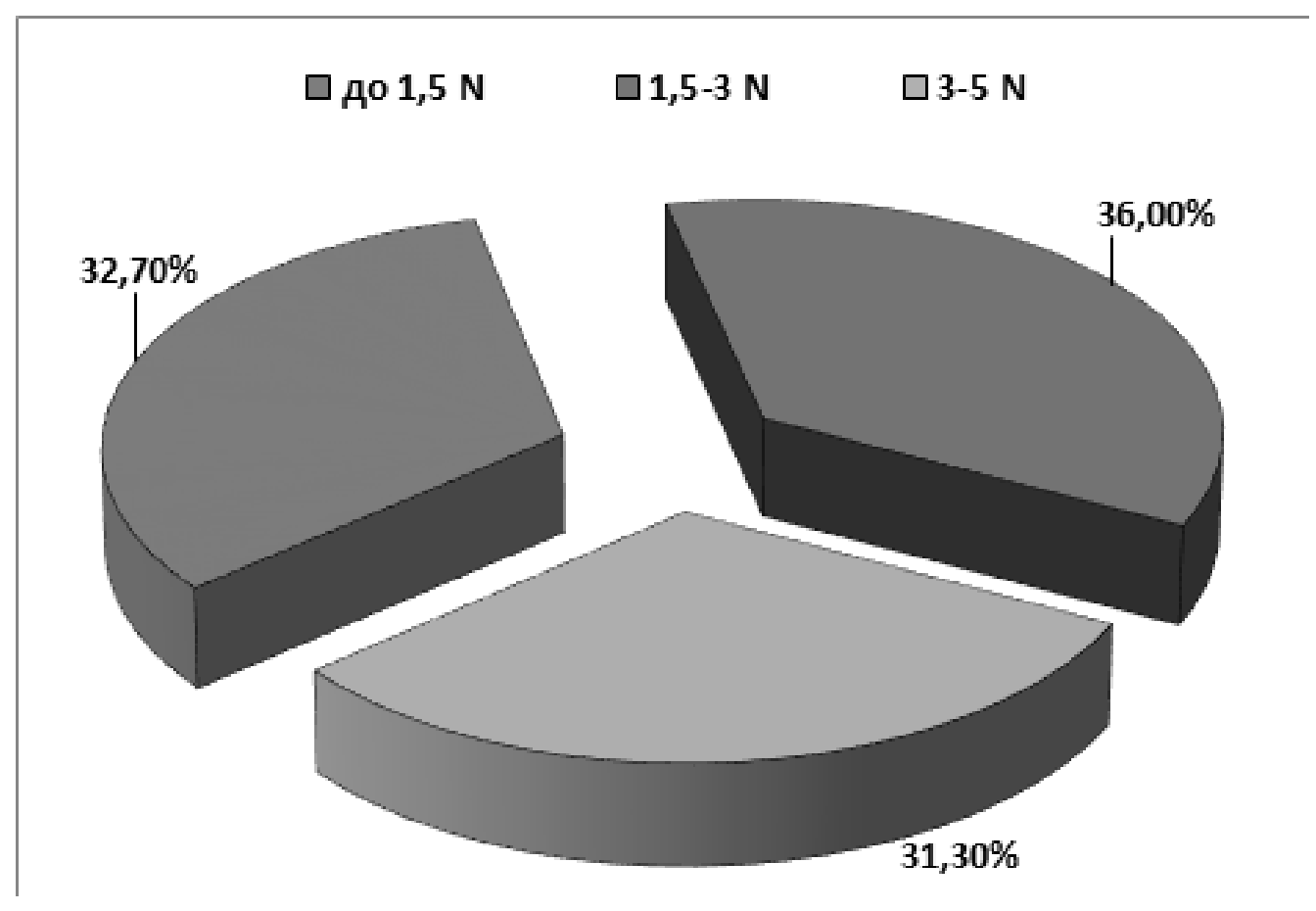

Рис. 3. Распределение больных ХГ С в зависимости от уровня цитолитических ферментов. 
Особенности клинических проявлений ХГ С у больных на момент включения в исследование представлены на рисунке 2 .

В таблице 1 представлены основные биохимические показатели крови больных ХГ С.

Как видно из таблицы 1, только содержание АлАТ, АсАТ и общего билирубина у исследованных больных было повышено по сравнению с нормальными показателями.

При сравнительном изучении цитолитических ферментов было установлено, что активность трансаминаз была нормальной (повышение до 1,5 раз) у 49 (32,7\%) больных, незначительно (1,5-3 норм) повышенной у 54 $(36,0 \%)$ и умеренной (3-5 норм) у 47 (31,3\%) пациентов (puc. 3).

В исследование включались только больные, у которых в крови выявлялись anti-HCV lg G. У всех 150 (100\%) больных при первичном обследовании в сыворотке крови обнаружен HCV RNA (признак репликации HCV). У всех больных определяли генотип ВГ С методом полимеразно-цепной реакции (ПЦР). При этом установлено, что 1-й генотип встречался у 98 $(65,3 \%)$ пациентов, 2-й у $15(10,0 \%)$ и 3-й генотип у $37(24,7 \%)$.

У 80 больных, которым была назначена терапия противовирусными препаратами, определяли вирусную нагрузку (ВН). Оказалось, что высокая вирусная нагрузка - более 800.000 ME/мл. наблюдалась у 33 (41,3\%) пациентов, а у 47 (58,7\%) низкая вирусная нагрузка менее 800.000 МЕ/мл. (таблица 2).

По данным иммуноферментного анализа, маркеры HBV-инфекции (HBs-Ag, HBs-Ab, HBe-Ag, HBe-Ab, HBcor$A b)$ у обследованных пациентов отсутствовали.

Из общего числа больных были сформированы 2 группы: лечения и сравнения, которые были рандомизированы по возрасту, полу, клинико-биохимическим показателям и результатам проведенной фиброэластометрии.

В таблице 3 представлены основные показатели лабораторного исследования больных основной группы и группы сравнения.

\section{Характеристика контрольной группы}

Контрольную группу составили 35 здоровых добровольцев в возрасте от 19 до 46 лет (средний возраст 32,5 $\pm 10,6$ лет), из них 23 (65,7\%) мужчины и 12 (34,3\%) женщин.

Различия по полу $(p=0,26)$ и возрасту $(p=0,24)$ с больными ХГ С были недостоверны.

В контрольную группу не включались лица, имеющие клинические признаки острых или хронических заболеваний любой природы. Всем лицам, включенным в контрольную группу, проводились общий и биохимические анализы крови, исследование маркеров HBV, HCV-инфекции иммуноферментным методом.

\section{ЛИТЕРАТУРА:}

1. Абдурахманов Д.Т. Латентная HBV-инфекция в патогенезе хро-нических заболеваний печени // Российский журнал гастроэнтерологии, гепатологии, колопроктологии. 2002. № 6.

2. Глушенков Д.В., Павлов Ч.С., Золотаревский В.Б., Маевская М.В., Ивашкин В.Т. Эластометрия у больных ХГ С на ранних стадиях фиброза печени // Российский журнал гастроэнтерологии, гепатологии, колопроктологии. 2007. T. XVII, № 5.

3. Ивашкин В.Т., Воликовский Л.Я., Тесаева Е.В. Первый российский опыт неинвазивной диагностики фиброза печени с помощью аппарата «ФиброСкан» // Российский журнал гастроэнтерологии и гепатологии. 2006. № 6.

4. Маевская, М.В. Лечение больных хроническим гепатитом С с исходно нормальным уровнем активности аланинаминотрансферазы // Российский журнал гастроэнтерологии, гепатологии, колопроктологии. 2005. T. XV, № 2.

5. Некрасова Т.П. Морфологическое исследование в оценке степени фиброза печени при хронических вирусных гепатитах // Гепатологический форум. 2007. № 2. 